\title{
BLOCKCHAIN TECHNOLOGY INTO STEEL INDUSTRY CURRENT STATE OF FOREIGN PAYMENT ACTIVITY
}

\author{
Yevhen Sotchenko ${ }^{1}$
}

\begin{abstract}
The purpose of the article is to analyze the current state of foreign trade in the industrial blockchain of the steel industry, the existing digital platform has gradually formed a large-scale heterogeneous distributed environment. The problems of further development of the metallurgical complex of Ukraine in the world electronic system of international cooperation are determined. Methodology. The survey is based on a blockchain technology is an interlinked systematic chain of blocks that contains transaction history and other user data. It works under the principle of decentralized distributed digital ledger. Results. Experimental tests prove that production companies, logistics, international payments and consumers can participate in the information certification of steel products via the modern information system. Consumers can understand the real product manufacturing process, effectively avoiding of the incomplete information and low transparency in the traditional information traceability process, and effectively trace the quality of steel products. The system provides an effective payments scheme for promoting the transformation and upgrading of the modern technology steel industry. Practical implications. In view of the low transparency of information traceability of current steel products and the defects of information islands, in this article the blockchain-based steel smart contract payment technology quality traceability system is developed and adopted the alliance chain mode and the new digital blockchain platform. The article describes the use of smart payment technology in a full-fledged financial transaction as a transfer funds in cryptocurrency to electronic bank accounts, as well as the transfer of commercial information, including contracts. To do this, the assets and terms of the contract are encoded and placed in the block chain, then the contract is distributed is saved on a set of network nodes and is executed after the condition is triggered. The fulfillment of the obligations of the parties is checked automatically. It is worth noting that the fact that smart contracts only react to transactions. If the asset or the currency is transferred to the program, it starts monitor compliance with the terms of the contract. How as soon as they are fulfilled, the seller receives money, and the buyer is a shipment goods. Value/originality. Blockchain technologies enable the use of business information systems that are highly resistant to technical failures and malicious attacks. Costs and time of carrying out business operations are significant.
\end{abstract}

Key words: exports, imports, metallurgical complex, foreign trade payments, steel production technology of blockchain, price, smart contract payments, crypocurrency, Smart Manufacturing, smart payment, smart structure.

JEL Classification: F13, F39

\section{Introduction}

The transformation of the global business environment under the influence of regressive factors causes the emergence of new crises in international economic relations. The interpretation of the word crisis, which comes from (Greek кpíøı - solution; reverse) creates a state in which existing means of achieving goals are inadequate, resulting in unpredictable situations that require the development of new approaches to problem situations. Crisis, as a phenomenon, reveals hidden conflicts and disproportions, and it can be considered as an independent phenomenon, an external factor, a political, sociological or economic category.

\footnotetext{
Corresponding author:

${ }^{1}$ Odessa I.I. Mechnikov National University, Ukraine.

E-mail: sjen@ukr.net

ORCID: https://orcid.org/0000-0002-4503-2351
}

The recent economic crisis that has gripped most national economies is manifested in the imbalance between supply and demand for goods and services. In a competitive economy, the relationship between business entities due to the crisis must undergo a massive transformation of business scenarios. Crisis phenomena in the economy can lead to the renewal of sociological, ideological, political conditions, and even lead to the reformation of national elites.

The COVID-19 pandemic has spread rapidly around the world, infecting millions of people and nearly halting economic activity, as most countries have imposed strict restrictions on movement to stop the spread of 
the virus. Over time, as health threats and human losses increase, the economic damage will become even more apparent and may become the greatest economic shock the world has experienced in decades.

The World Bank as immediate, as is the immediate pandemic impact and long-term growth due to the damage it has caused has identified the global economic outlook for June 2020. The baseline forecast predicts a 5.2 percent contraction in world GDP in 2020, the deepest global recession in decades, despite governments' extraordinary efforts to counter the economic downturn with support for fiscal and monetary policies. In the longer term, the deep recessions caused by the pandemic will leave long-term scars due to declining investment, "erosion" of human capital due to job or training loss, fragmentation of global trade and supply links.

The pandemic crisis requires the development of urgent measures needed to mitigate the effects on public health and economic recovery.

The metallurgical complex is one of the main elements of economy of Ukraine and plays very important role in its future development. Metallurgy is a major contributor to the budget, the main provider of foreign currency in Ukraine. Production of the metallurgical complex is the main component of export of industrial branch of the country in this connection an actual problem is research of a current state and prospects of development of the foreign trade activity of a metallurgical complex. It should be noted that exact production of metallurgical complex plays a key role of definition of foreign economic activity positive influences on subjects of managing on formation of key macroeconomic indicators to which it is necessary to carry: acceptability of a condition of the balance of payments of the country, inflationary expectations and cost of national monetary unit.

\section{Analysis of recent research and publications, results and discussion}

Among domestic and foreign scholars who have dedicated their works to the problems of foreign trade activity of metallurgical complex should be mentioned I.P. Bulev I.P. (Bulev, 2013), Mazur V.L. (Mazur, 2010), Sardak S., Stavyts'ka A. (Research of the structure and development trends of world market of information technologies, 2015) and others. The presenters in the hallucinations of smart structures were occupied by such presenters, Satoshi Nakomoto (Nakomoto, 2020), George Doran (Doran, 1981), Nick Sabo (Sabo, 2003).

The purpose of this study is to analyze the current state of foreign trade activity of World Ukraine's metallurgical complex and to emphasize problems of effective further development of metallurgical complex with blockchain technology in the modern system of international cooperation.
In the world economy, the key factor of stability and high competitiveness in the end should be a policy of constant innovation to implement innovative technological solutions in the field of information technology, development of new international settlement tools, which requires banks and other market participants to make quick and radical decisions. Model of their financial behavior and strategic line of development of organizational structure. A special place is occupied by the so-called smart structures and technologies based on them, which are widely used in various fields of human activity.

Smart Structure (Smart Structure) is a system that contains multifunctional parts that can monitor and activate control; and can act as a primitive analogue of a biological body. To build such intelligent constructions, software is used that can perform the functions of monitoring and tracking the operation of individual parts of the software application using a predicate system as an expression that uses one or more values with the result of a logical type. One of the most well known smart structures in the world of information technology is the concept of smart contracts, which appeared in 1994, when cryptographer and legal expert Nick Szabo introduced it to use the developed methods of contract law in e-commerce protocols on the Internet. This researcher is also one of the developers of bit gold. Back in 1996, he argued that the minimum amount of micropayment is determined not so much by technology as by the reasonable effort required to evaluate the product and the decisions made, or, in his words, "its transaction value".

However, in practice, the realization of this idea was received only in 2008, thanks to the advent of blockchain technology in bitcoin cryptocurrencies (Nakamoto, 2020). Next, consider the concept of SMART as an mnemonic abbreviation, the components of which are criteria for setting tasks, such as in project management, management and personal development. This abbreviation was first mentioned in November 1981 . In a publication by George T. Doran for Management Review (Doran, 1981), formed from the words of English. Specific, measurable, assignable, realistic, timerelated - concrete, measurable, has a performer, realistic, limited in time. It is believed that the compliance of tasks with these criteria significantly increases the likelihood of their implementation to achieve the goal. For a more detailed idea of smart payment, first consider the standard forms of documentary payments, which are widely used in the implementation of foreign trade agreements and payments for them (Sabo, 2003).

\section{Practical application of blockchain technologies in business}

As an example, we would like to cite the deal between Alfa-Bank together with Gazpromneft-Aero, the 
operator of the aviation fuel business Gazprom Neft, and S7 Airlines, which launched a blockchain service that allows airlines to pay instantly for fuel directly when refueling aircraft without prepayment, banks guarantees and financial risks for the parties to the transaction.

The service is based on Aviation fuel smart contracts (AFSC), which run on the blockchain platform HyperLedger. Through the AFSC system, the airline transmits to the supplier information about refueling the desired flight, agrees on the preliminary volume of fuel and its price. This data is used to assign a technical task to the driver of the tanker at the airport.

Next, the commander of the aircraft in the system requests from the operator the required amount of fuel, after which the online application is sent to the airline's bank to reserve the required amount in the carrier's account. Instant confirmation from the bank starts refueling. After the service is performed, the funds are written off, and the commercial services of the fuel supplier and the air carrier are sent information about the closure of the application for refueling and reporting documents. The new technology multiplies the speed of financial transactions and reduces the labor costs of airline staff and suppliers.

As an industry leader, Gazpromneft-Aero is not only a conductor of IATA international standards for aviation fuel supply in Russia, but also actively implements the world's best practices and innovative solutions aimed at improving business efficiency. The use of this technology in mutual settlements between airlines and fuel operators will give a new impetus to the development of the entire aviation industry, "said Vladimir Egorov, CEO of Gazpromneft-Aero.

"As a technology leader in the industry, S7 Airlines analyzes and, with sufficient justification, implements promising technologies, including blockchain. We were the first to use smart contracts for letters of credit. After that, they developed a blockchain platform for automating trade transactions between several counterparties and launched a service on it for mutual settlements with agents selling air tickets. Our next step is a service to automate payments for fuel supply. It is an automated trading operation between three parties: a bank, an airline and a tanker. Upon refueling the aircraft according to the pre-established rules, the funds are reconciled and written off. The technology allows to increase the transparency of mutual settlements, to abandon a number of manual operations and speed up processes, "said Pavel Voronin, Deputy General Director for Information Technology of S7 Group.

Made analysis of current state supply chain around the world revealed to become increasingly interconnected, the influence of blockchain is becoming more prevalent. The Factory of the Future spans across a whole network of steel production. Now, more than ever before, manufacturers face the challenge of securely sharing data within and outside industry walls (Riddle \& Code,
2021; Ukrmetprom, 2020; Manufacturing Global, 2021; GMK Center, 2021).

To work out the best practice for blockchain, a manufacturer must conduct a structured assessment, which begins with identifying the company's current business problems and future needs. Subsequently, it can then explore how it leverages the technology to relieve the factory's pain points and addresses its needs. Equipped with a strong understanding of the opportunities and challenges it faces, the manufacturer can then choose the most appropriate option from the available technology solutions. (Yan Cao, 2021).

Be reviewed the current situation on the global steel products market (Figure1). China is estimated to have produced 83.0 Mt in February 2021, up 10.9\% on February 2020. India produced $9.1 \mathrm{Mt}$, down $3.1 \%$. Japan produced 7.5 Mt, down 5.6\%. The United States produced 6.3 Mt, down 10.9\%. Russia is estimated to have produced $5.7 \mathrm{Mt}$, down $1.3 \%$. South Korea produced $5.5 \mathrm{Mt}$, up $1.2 \%$. Turkey produced $3.0 \mathrm{Mt}$, up $5.9 \%$. Germany produced $3.1 \mathrm{Mt}$, down $10.4 \%$.

Regions and countries covered by the table 1 :

- Africa: Egypt, Libya, South Africa;

- Asia and Oceania: Australia, China, India, Japan, New Zealand, Pakistan, South Korea, Taiwan (China), Vietnam;

- CIS: Belarus, Kazakhstan, Moldova, Russia, Ukraine, Uzbekistan;

- European Union (27);

- Europe, Other: Bosnia-Herzegovina, Macedonia, Norway, Serbia, Turkey, United Kingdom;

Table 1

Top 10 steel-producing countries

\begin{tabular}{|l|c|c|c|c|}
\hline \multicolumn{1}{|c|}{ countries } & $\begin{array}{c}\text { Feb 2021 } \\
(\mathrm{Mt})\end{array}$ & $\begin{array}{c}\text { \% change } \\
\text { Feb } \\
21 / 20\end{array}$ & $\begin{array}{c}\text { Jan-Feb } \\
2021 \\
(\mathrm{Mt})\end{array}$ & $\begin{array}{c}\text { \% change } \\
\text { Jan-Feb } \\
21 / 20\end{array}$ \\
\hline Africa & 1.2 & -6.4 & 2.4 & -6.9 \\
\hline Asia and Oceania & 109.7 & 7.5 & 230.8 & 10.1 \\
\hline CIS & 8.0 & -1.5 & 16.8 & -0.4 \\
\hline EU (27) & 11.9 & -7.1 & 24.1 & -3.7 \\
\hline Europe, Other & 3.9 & 5.2 & 8.2 & 6.9 \\
\hline Middle East & 3.2 & -0.9 & 6.8 & 0.4 \\
\hline North America & 8.8 & -8.9 & 18.5 & -7.1 \\
\hline South America & 3.5 & 2.2 & 7.3 & 6.6 \\
\hline Total 64 countries & $\mathbf{1 5 0 . 2}$ & $\mathbf{4 . 1}$ & $\mathbf{3 1 5 . 0}$ & $\mathbf{6 . 6}$ \\
\hline
\end{tabular}

Source: (Worldsteel, 2021)

- Middle East: Iran, Qatar, Saudi Arabia, United Arab Emirates;

- North America: Canada, Cuba, El Salvador, Guatemala, Mexico, United States;

- South America: Argentina, Brazil, Chile, Colombia, Ecuador, Paraguay, Peru, Uruguay, Venezuela.

As reported earlier, in 2019, companies of Ukraine's mining \& metals sector decreased production of steel by $1.2 \%$ to 20.85 million tons, pig iron by $2 \%$ to 20.6 


\section{Crude steel production}

200

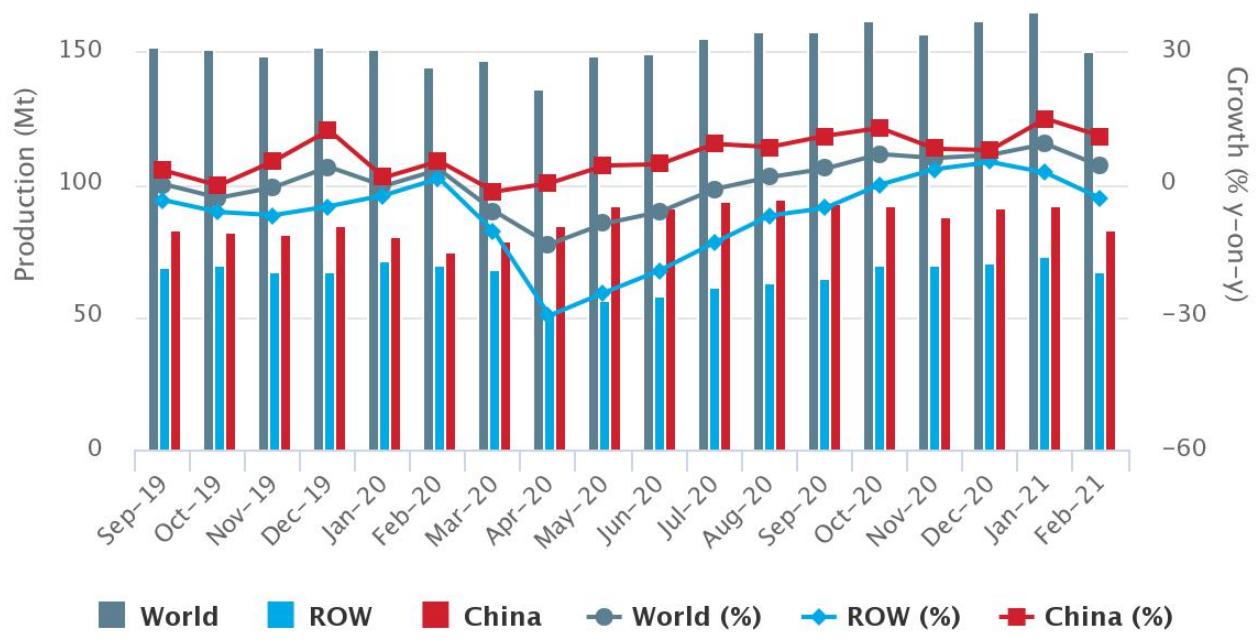

Figure 1. Pattern of growth to world steel production markets

Source: (Worldsteel, 2021)

million tons, rolled products by $0.9 \%$ to 18.2 million tons against 2018 (Manufacturing Global, 2021).

\section{Prospects for the use of blockchain technologies in the steel industry of Ukraine}

The Ukrainian iron and steel industry is concentrated in central (Dnipro, Kryvyi Rih, Nikopol), southern (Zaporizhzhia) and eastern (Donets Basin, Mariupol) regions of Ukraine. There are 14 iron ore mining companies, 15 iron and steel mills, and three ferroalloy plants (Wikipedia, 2021).

To review of the situation before the crisis in Ukraine in the field of iron and steel as a whole In the pre-crisis times the share of metallurgical complex was $27 \%$ in the gross domestic product of Ukraine. More than $40 \%$ of currency came to the state from metallurgy and it affected state of the economy of the country in crisis. In the conditions of world decline in demand for metal inflow of currency considerably decreased, and the economy experienced decrease much more, than was predicted. The gain of sales proceeds was considerably reduced (Table 2 ).

In recent years, the metallurgical complex development is influenced negatively by adverse external economic conditions, which are characterized by decrease in the world prices for ferrous metals. A competition aggravation in the markets of Europe and Asia against surplus in the world of capacities, domination in the market of cheap Chinese hire, reduction of demand for metallurgical production in the Middle East which traditionally is one of the greatest consumers of the Ukrainian metallurgical production. In 2013 from Ukraine about 26,5 million $\mathrm{t}$ are exported metal production that for 3,6\% exceeds the indicators 2012 (Steemit, 2020). In recent years, development of metallurgical complex is influenced negatively by adverse external economic conditions which are characterized by decrease in the world prices for ferrous metals, a competition aggravation in the markets of Europe and Asia against surplus in the world of capacities, domination in the market of cheap Chinese hire, reduction of demand for metallurgical production in the Middle East which traditionally is one of the greatest consumers of the Ukrainian metallurgical production. In 2013 from Ukraine about 26,5 million $t$ are exported metal production that for 3,6\% exceeds the indicators 2012 (Mazur, 2010).Reduction of prices in the world markets of metal and metallurgical production led to that in value terms export deliveries of steel products made about $14,3 \mathrm{bln}$. USD that is $6,7 \%$ less, than in 2012. Export deliveries of metal production in 2013 in comparison with 2012 increased by $1,1 \%$, in value terms export deliveries of metal production exceeded 1459 million USD (Table 2).

Dynamics of export-import coverage ratio from the point of view of domestic metallurgical complex is given in Figure 1. As show data of Figure 1 value of exportimport coverage ratio from the point of view of domestic metallurgical complex is big units in all studied period.

Data of Figure 2 indicate a negative in development of foreign economic activity of subjects of metallurgical 
complex which essence is reduced to the available tendency concerning reduction of coefficient of a covering of export by import of metal production.

The insufficient nomenclature of production of deep processing by the domestic metallurgical companies causes strengthening of its import, first of all machine-building enterprises which consume about a quarter of total amounts of the Ukrainian import of metal production. According to experts, because of the insufficient nomenclature iron and steel works annually receives less about 3 billion USD (State Statistics Service of Ukraine, 2020). Excessive orientation of the domestic enterprises to export of raw production which production demands considerably smaller expenses is the main reason. At present, the global metallurgical market is undergoing significant changes under the influence of the rapid development of China's economy, which not only had a lot of produce, but also actively buys metal and iron ore for its domestic market. In the case of a decrease in demand for metallurgical products of Chinese industry the surplus of produced products are supplied to the world market at very low prices, forcing other manufacturers also to reduce the prices of the metal (Figure 2). This situation has a negative impact on the metallurgical industry in Ukraine, a major exportoriented industry. Therefore, in order to maintain its competitive position and development of new markets for Ukrainian producers and topical issues are finding ways to adapt to changes in the world market and the choice of an effective competitive strategy of foreign trade. One of the effective methods of international management company is the concentration of capital and production capacity through vertical integration of production, which includes organizational business combination, related manufacturing operations under common ownership. With the increased competition on the market, the domestic enterprises are vulnerable to major problems that have accumulated in the branch:

- a significant lag behind developed countries in terms of modernization;

- the high cost of energy and material resources compared with leading;

- foreign companies;

- an assortment of metal is not wide;

- poor environmental performance.

Foreign trade activity allows metallurgical companies to obtain the economic, scientific-technical and social effects. The decline of the volume of production, the artificial reduction of financial results, raw insecurity of production flows out not from world markets and domestic market factors, but, first of all, out of problems of management of metallurgical enterprises. So, wellchosen competitive strategy of foreign trade activity is the key to efficient operation of the business in the global industry market.

Table 2

Sales proceeds of the metallurgical companies in 2011-2012

\begin{tabular}{|l|c|c|c|}
\hline \multicolumn{1}{|c|}{ Company } & 2011 & 2012 & Rate of growth, $\%$ \\
\hline Azovstal & 35786 & 44423 & 24,14 \\
\hline Metinvest & 26175 & 35759 & 36,62 \\
\hline ArcelorMittal & 24280 & 29889 & 23,1 \\
\hline Alchevsk iron and steel works & 12208 & 21770 & 61,38 \\
\hline Yenakiieve iron and steel works & 13238 & 21363 & 34,86 \\
\hline Zaporizhstal & 14368 & 19376 & 45,33 \\
\hline Dneprovsk iron and steel works & 12574 & 18273 & $-26,97$ \\
\hline Nikopol ferroalloy plant & 10767 & 7863 & -58 \\
\hline Makiivka iron and steel works & 6557 & 2753 & $-4,3$ \\
\hline Stakhanov ferroalloy plant & 1632 & 1561 & $-0,4$ \\
\hline Kremenchuk steel works & 1376 & 1370 & 0,4 \\
\hline Donetsksteel iron and steel works & 780 & 784 & \\
\hline
\end{tabular}

Source: (Wikipedia, 2021)

Table 3

Main indicators of the foreign trade activity of Ukraine's metallurgical complex in 2008-2013

\begin{tabular}{|l|c|c|c|c|c|c|}
\hline \multicolumn{1}{|c|}{ Indicators } & 2008 & 2009 & 2010 & 2011 & 2012 & 2013 \\
\hline Exports, mln. USD & 1261,9 & 1175,2 & 1548,0 & 1916,2 & 1327,3 & 1459,5 \\
\hline in \% to previous year & 5,7 & 6,9 & 31,7 & 23,7 & 30,8 & 1,1 \\
\hline Imports, mln. USD & 270,7 & 250,8 & 448,3 & 465,4 & 394,0 & 387,8 \\
\hline in \% to previous year & 7,2 & 7,4 & 78,7 & 3,8 & 15,4 & 1,6 \\
\hline Balance, mln. USD & 991,2 & 924,4 & 1099,7 & 1450,8 & 933,3 & 1071,7 \\
\hline Export-import coverage ratio & 4,66 & 4,68 & 3,45 & 4,12 & 3,36 & 3,76 \\
\hline
\end{tabular}

Source: (Ukrmetprom, 2021) 
Vol. 2 No. 1, 2021

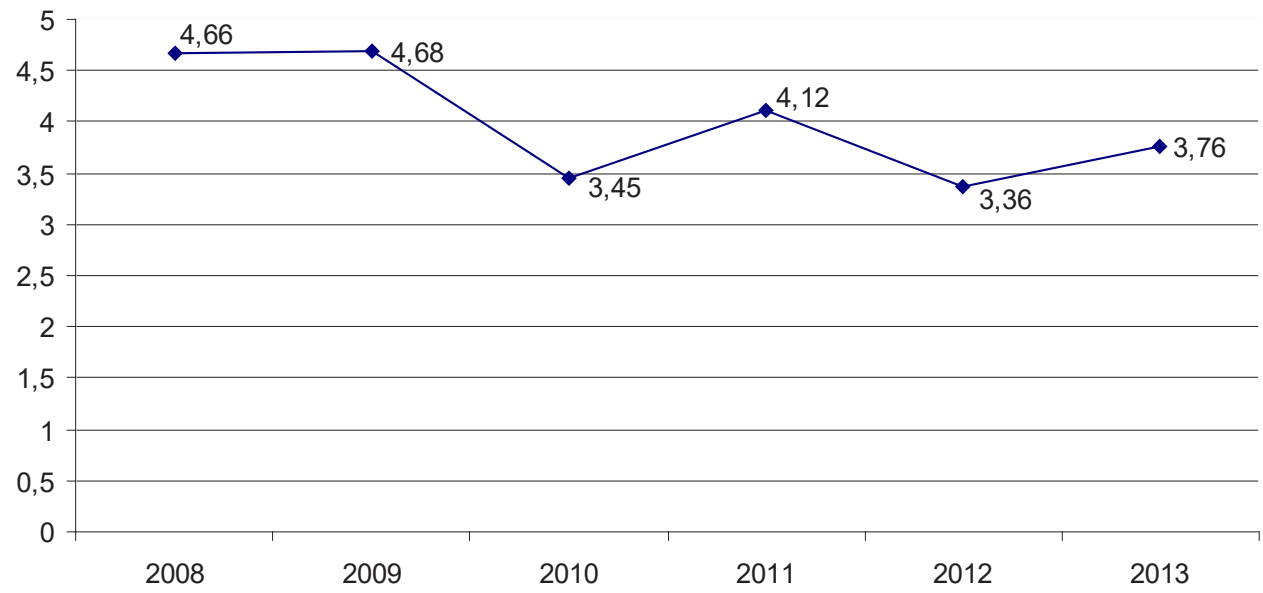

Figure 2. Dynamics of export-import coverage ratio in metallurgical complex

Source: (Ukrmetprom, 2021)

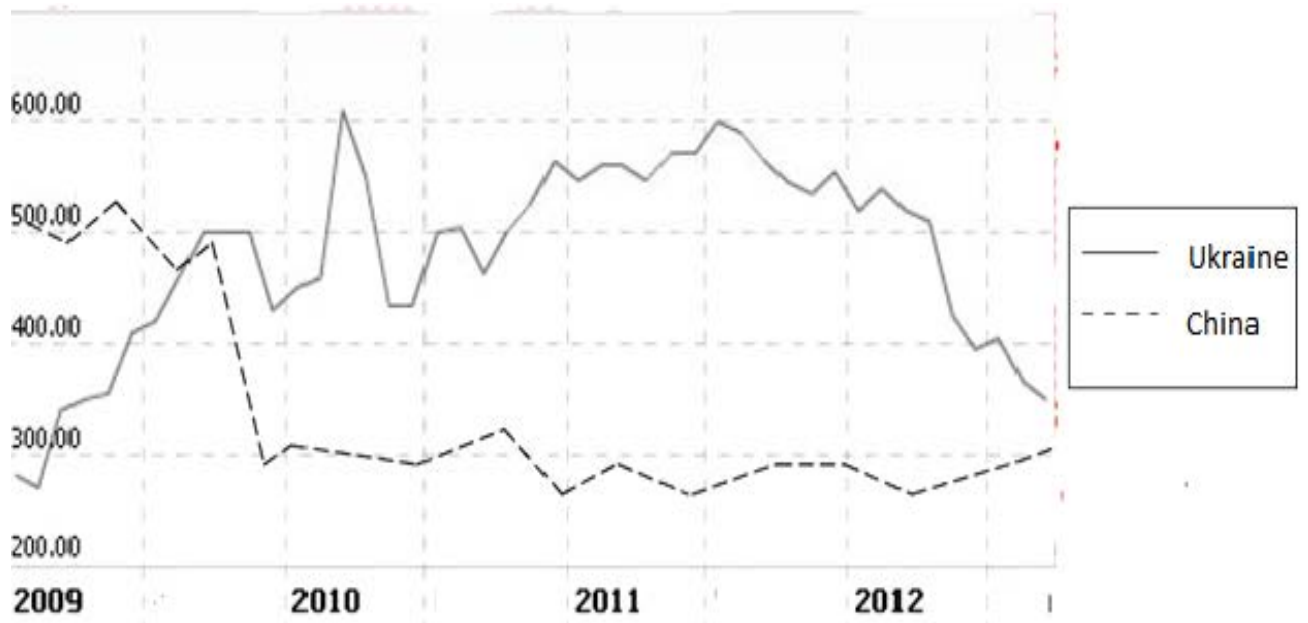

Figure 3. Prices for the metal in Ukraine (compared to China), USD/t

Source: (Problemi innovatsiyno-investitsiynogo rozvitku, 2013)

\section{Conclusions}

Foreign trade activity of the metallurgical complex is of strategic importance for the national economy. The main contribution of metallurgy makes to the budget was the main supplier of foreign exchange in Ukraine. Now, there is a decline in the production of metal products in comparison with the pre-crisis period of observations.

The efficiency of foreign trade activities of the metallurgical complex affects not only the macroeconomic indicators of the country's development, but also the welfare of the population, since the industry is the main source of foreign exchange earnings in Ukraine. Thus, the competitive strategy of foreign trade activities of domestic metallurgical exporters should include the development of a management mechanism based on a comprehensive modernization of its technical re-equipment, energysaving technologies, and the introduction of new information technologies based on the blockchain. This will allow domestic producers of metallurgical products to shorten the supply and settlement chain to effectively compete in the global market and harmonize the interests of the company and its owners and minimize the risks of fraudulent transactions within the international business environment.

\section{References:}

Bulev, I. P., \& Bryuhovetskaya, N. E. (2013). Zadachi reformirovaniya gorno-metallurgicheskogo kompleksa Ukrainy. Ekonomika promyishlennosti, vol. 1-2 (61-62), pp. 219-230.

Doran, G. T. (1981). There's a S.M.A.R.T. way to write management's goals and objectives. Management Review, vol. 70, issue 11 (AMA FORUM), pp. 35-36. 
How blockchain can revolutionise the metal industry. (n.d.-a). RIDDLE\&CODE THE BLOCKCHAIN INTERFACE COMPANY. Available at: https://www.riddleandcode.com/how-blockchain-can-revolutionisethe-metal-industry (accessed 28 April 2021).

Is dag technology the future of payments? Official site Steemit. Available at: https://steemit.com/dag/@edicted/ is-dag-technology-the-future-of-payments (accessed 4 December 2020).

Mazur, V. L. (2010). Metallurgiya Ukrainyi: sostoyanie, konkurentosposobnost, perspektivyi. Metallurgicheskaya i gornorudnaya promyishlennost, vol. 2, pp. 10-14.

Metal production in Ukraine - Wikipedia (n.d.) [Official portal]. Wikipedia. Available at: https://en.wikipedia.org/ wiki/Metal_production_in_Ukraine (accessed 28 April 2021).

Nakamoto - Bitcoin A Peer-to-Peer Electronic Cash System.pdf' (no date). Available at: https://bitcoin.org/ bitcoin.pdf (accessed 1 November 2020).

Sardak S., \& Stavyts'ka A. (2015). Research of the structure and development trends of world market of information technologies. Technology audit and production reserves, vol. 5(24), pp. 96-100.

State Statistics Service of Ukraine. Statistical Yearbook. Kyiv, 2020.

Szabo, Nick The Mental Accounting Barrier to Micropayments. System. Available at: https://nakamotoinstitute.org/ static/docs/micropayments-and-mental-transaction-costs.pdf (accessed 5 December 2020).

The Results of the Mining \& Metallurgical Complex of Ukraine Activity for 10 months 2020 (2020 November 13). Available at: https:ukrmetprom/org/the-results-of-the-mining-metallurgical-complex-of-ukraine-activity-for-10months-2020 (accessed 28 April 2021).

The role of blockchain in manufacturing.Smart Manufacturing. Manufacturing Global (n.d.). Available at: https://www.manufacturingglobal.com/smart-manufacturing/role-blockchain-manufacturing (accessed 28 April 2021).

Why the steel industry needs blockchain - Opinions - GMK Center (n.d.). GMK. Available at: https://gmk.center/en/opinion/why-the-steel-industry-needs-blockchain/ (accessed 28 April 2021).

Worldsteel. February 2021 crude steel production (n.d.). Available at: http://www.worldsteel.org/media-centre/ press-releases/2021/February-2021-crude-steel-production.html (accessed 28 April 2021).

Yan Cao (n.d.-a). Efficient Traceability Systems of Steel Products Using Blockchain-Based Industrial Internet of Things [Webportal]. IEEE Xplore. Available at: https://ieeexplore.ieee.org/document/8843946/ (accessed 28 April 2021). 